\title{
Synthesizing Drainage Morphology of Tectonic Watershed in Upper Ing Watershed (Kwan Phayao Wetland Watershed)
}

\author{
Rangsan Ket-ord ${ }^{1}$, Nipon Tangtham ${ }^{2} \&$ Veerasak Udomchoke ${ }^{3}$ \\ ${ }^{1}$ Faculty of Environment, Kasetsart University, Bangkok, Thailand \\ ${ }^{2}$ Forest Research Center, Faculty of Forestry, Kasetsart University, Bangkok, Thailand \\ ${ }^{3}$ Department of Earth Sciences, Faculty of Science, Kasetsart University, Bangkok, Thailand \\ Correspondence: Rangsan Ket-ord, Faculty of Environment, Kasetsart University, Bangkok 10900, Thailand. Tel: \\ 66-8-9525-5469. E-mail: rangsank@gmail.com
}

Received: November 12, $2012 \quad$ Accepted: December 1, $2012 \quad$ Online Published: December 7, 2012

doi:10.5539/mas.v7n1p13 URL: http://dx.doi.org/10.5539/mas.v7n1p13

\begin{abstract}
The study was aimed to synthesize drainage morphology of tectonic watershed in upper Ing Watershed in Phayao province, northern Thailand. The morphometric analysis of 12 sub-watersheds was carried out using Geographic Information System (GIS) software-ArcGIS 9.3 for analysing drainage pattern and calculating the 16 theoretical values of drainage morphometric parameters in 3 aspects including linear aspect, areal aspect and relief aspect. The geologic formation and structure are also overlain on drainage morphological map to determine their influence on drainage patterns. The results showed that most areas were dendritic drainage pattern, while rectangular drainage pattern occurs relative to the direction of the fault. Trellis drainage pattern shown on the northeast of the watershed in Mae Puem sub-watershed which the rock layers bend or tilt in syncline structural geology. The upper Ing watershed was classified as a third to fifth order streams, which controlled by physiographic and structural conditions. The tectonic force formed a graben basin which Kwan Phayao wetland is the lowest area of this graben while the high mountain ranges in the western area. As a result, the river is flowing from western highland to lowland quickly especially in the western sub-watershed, this result affecting low permeability, high discharge of runoff and intensity of erosion processes which the calculated drainage morphometric parameters showed the results according to their appearance. It could be said that the drainage patterns in this area is influenced by tectonic structure rather than geologic formation. This study provided more understanding in drainage morphological characteristics of the upper Ing watershed for planning sustainable management of the Kwan Phayao wetland.
\end{abstract}

Keywords: drainage morphology, tectonic watershed, upper Ing watershed, Kwan Phayao wetland

\section{Introduction}

Upper Ing watershed lay on the north of Phi Pun Nam ranges, situated in the southern of Phayao-Chiang Rai basin, which is a part of Mekong watershed. The watershed was affected from tectonic forces that formed a graben along the fault. Kwan Phayao is the lowest area of this graben which accumulated water, sediments, nutrients, and poisonous substances. Kwan Phayao is very important for consumptions, fisheries, agricultures, and accommodated surplus flooding in rainy season. Moreover, its features indicated "a wetland" according to the international convention on wetlands (Ramsar Convention) (Office of natural resources and Environmental policy and planning, 1999). Morphometric analysis provides quantitative description of the basin geometry to understand initial slope or inequalities in the rock hardness, structural controls, recent diastrophism, geological and geomorphic history of drainage basin (Strahler, 1964). Many workers have carried out morphometric analysis using remote sensing and geographic information system (GIS) techniques includes Vittala et al. (2004), Chopra et al. (2005), Narendra and Nageswararao (2006), Ozdemir and Bird (2009), Thomas et al. (2011), Chitra et al. (2011), Zende and Nagrajan (2011), and Magesh et al. (2012). This study aimed to understand the drainage morphology in upper Ing watershed. The 16 value of drainage morphometric parameters were calculated in 3 aspects include linear aspect, areal aspect, and relief aspect. The knowledge of this study will be beneficial to management of Kwan Phayao wetlands.

The objectives of this study consist of: 
1) To study drainage pattern in upper Ing watershed which affected from geomorphological conditions and related to the fault directions in this area.

2) To analyze the drainage morphology by using GIS and synthesis the drainage patterns based on the related drainage morphological theories.

The result of this study can be divided into four parts. The first part is the patterns of drainage system; the second part is the drainage morphology; the third part is the drainage morphometric parameters of each drainage pattern; and the fourth part is geological structural control on drainage morphology.

\section{Study Area}

The upper Ing watershed is a part of Mekong watershed, located between $19^{\circ} 01^{\prime \prime} 21^{\prime \prime}$ to $19^{\circ} 32^{\prime} 53^{\prime \prime} \mathrm{N}$ in latitude and $99^{\circ} 41^{\prime 2} 24^{\prime \prime}$ to $99^{\circ} 57^{\prime} 32^{\prime \prime} \mathrm{E}$ in longitude. The area of this watershed is 1,148.92 square kilometers, including MuangPhayao district, Mae Chai district, and some parts of Dok Kham Tai district. Furthermore, some areas are in Parn district and Phadad district in ChaingRai province, which Ing River is the main stream of this area. This watershed consists of 12 sub-watersheds, which is a plain in the middle of watershed. There are many large swamps such as Kwan Phayao and NongLengSai swamp. The highland and mountains are in the west side, while the areas between plain and highland are undulating and rolling phase. Those of topographical features were formed by tectonic forces which collapsed along the fault and occured a large graben. Thus, a lowest area of the graben is Kwan Phayao. The functions of this watershed are collecting and storing water and sediments that flowed from the highland in northwest and west side. Then, the IngRiver flows backward into Mekong River at Chaing Kong district in ChaingRai province (Figure 1).

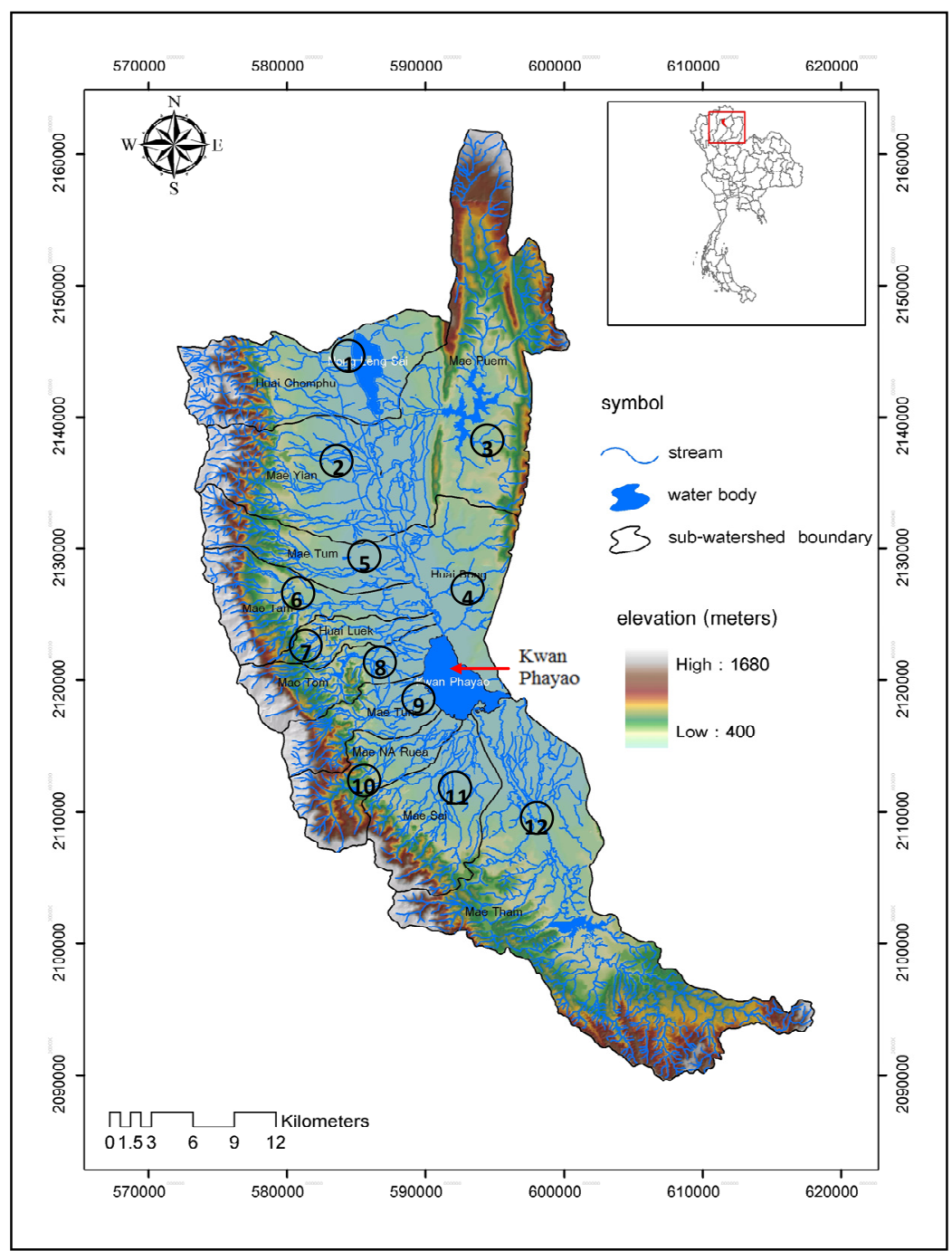

Figure 1. Location of the study area with topography and stream network 


\section{Method}

The flowchart summarizes the methodology of the study as shown in Figure 2. Different components of the methods are detailed below:

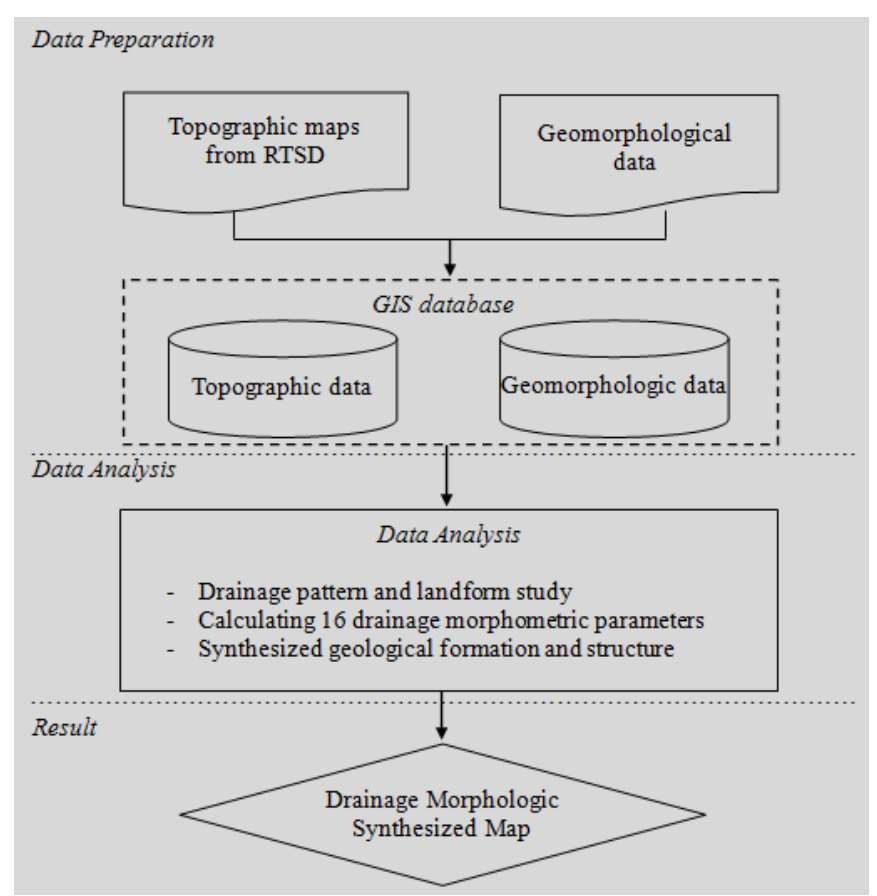

Figure 2. Methodology for synthesizing drainage morphology

\subsection{Data Preparation}

The based map of upper Ing watershed based on the Royal Thai Survey Department (RTSD) topographic maps on a 1:50,000 scale was prepared and imported to Geographic Information System (GIS) software-ArcGIS 9.3 platform. This software has been used for digitization and computational purpose and also for output generation.

\subsection{Data Analysis}

\section{1) Geomorphological Study}

To study the geomorphological structure of tectonic watershed including landform and drainage pattern by review literature and field surveying to check the accuracy of geological and topographic maps and compare with the real appearances such as the rock and the fault occured, the posing of the sediment and the drainage stream flowed.

\section{2) Synthesizing Drainage Morphology}

Calculating the 16 theoretical value of drainage morphometric parameters including (a) linear aspects like stream order, stream number, stream length, mean stream length, stream length ratio, bifurcation ratio, mean bifurcation ratio (b) areal aspects like drainage density, drainage texture, stream frequency, form factor, elongation ratio, circularity ratio, length of overlandflow and (c) relief aspects like watershed relief, relief ratio, ruggedness number (Table 1) and using GIS for overlay the geologic formation and tectonic structure maps on drainage morphological map in order to determine their influence on drainage patterns. 
Table 1. Drainage morphometric parameters

\begin{tabular}{|c|c|c|c|c|}
\hline No. & Aspects & Parameters & Formulae & References \\
\hline 1 & \multirow{6}{*}{$\begin{array}{c}\text { Linear } \\
\text { Aspects }\end{array}$} & Stream Order $(\mathrm{U})$ & Hierarchial rank & Strahler (1964) \\
\hline 2 & & Stream Length $(\mathrm{Lu})$ & Length of the stream & Horton (1945) \\
\hline 3 & & $\begin{array}{l}\text { Mean Stream } \\
\text { Length }(\mathrm{Lsm})\end{array}$ & $\begin{array}{l}\text { Lsm }=\mathrm{Lu} / \mathrm{Nu} \\
\text { Where, } \quad \mathrm{Lsm}=\text { mean stream length } \\
\qquad \mathrm{Lu}=\text { total stream length of order ' } \mathrm{u} \text { ' } \\
\mathrm{Nu}=\text { total no. of stream segments of order ' } \mathrm{u} \text { ' }\end{array}$ & Strahler (1964) \\
\hline 4 & & $\begin{array}{l}\text { Stream Length Ratio } \\
\text { (RL) }\end{array}$ & $\begin{array}{ll}\mathrm{RL}=\mathrm{Lu} /(\mathrm{Lu}-1) \\
\text { Where, } & \mathrm{RL}=\text { stream length ratio } \\
& \mathrm{Lu}=\text { total stream length of order ' } \mathrm{u} \text { ' } \\
& \mathrm{Lu}-1=\text { total stream length of its next lower order }\end{array}$ & Horton (1945) \\
\hline 5 & & $\begin{array}{l}\text { Bifurcation Ratio } \\
\qquad(\mathrm{Rb})\end{array}$ & $\begin{array}{ll}\mathrm{Rb}=\mathrm{Nu} /(\mathrm{Nu}+1) \\
\text { Where, } & \mathrm{Rb}=\text { bifurcation ratio } \\
& \mathrm{Nu}=\text { total no. of stream segments of order ' } \mathrm{u} \text { ' } \\
& \mathrm{Nu}+1=\text { no. of stream segments of next higher order }\end{array}$ & Schumm (1956) \\
\hline 6 & & $\begin{array}{l}\text { Mean Bifurcation } \\
\text { Ratio (Rbm) }\end{array}$ & $\mathrm{Rb}=$ average of bifurcation ratios of all orders & Strahler (1957) \\
\hline 7 & \multirow{7}{*}{$\begin{array}{c}\text { Areal } \\
\text { Aspects }\end{array}$} & $\begin{array}{l}\text { Drainage Density } \\
\text { (Dd) }\end{array}$ & $\begin{array}{l}\mathrm{Dd}=\mathrm{Lu} / \mathrm{A} \\
\begin{array}{l}\text { Where, }, \mathrm{Dd}=\text { drainage density } \\
\mathrm{Lu}=\text { total stream length of all orders } \\
\mathrm{A}=\text { area of the basin }\left(\mathrm{km}^{2}\right)\end{array}\end{array}$ & Horton (1932) \\
\hline 8 & & $\begin{array}{l}\text { Drainage Texture } \\
\text { (Rt) }\end{array}$ & $\begin{array}{ll}\mathrm{Rt}=\mathrm{Nu} / \mathrm{P} & \\
\text { Where, } & \mathrm{Rt}=\text { drainage texture } \\
& \mathrm{Nu}=\text { total no. of streams of all orders } \\
& \mathrm{P}=\text { perimeter }(\mathrm{km})\end{array}$ & $\begin{array}{l}\text { Horton }(1945) \\
\text { Smith }(1950)\end{array}$ \\
\hline 9 & & $\begin{array}{l}\text { Stream Frequency } \\
\text { (Fs) }\end{array}$ & $\begin{array}{ll}\mathrm{Fs}=\mathrm{Nu} / \mathrm{A} & \\
\text { Where, } & \mathrm{Fs}=\text { stream frequency } \\
& \mathrm{Nu}=\text { total no. of streams of all orders } \\
& \mathrm{A}=\text { area of the basin }\left(\mathrm{km}^{2}\right)\end{array}$ & Horton (1932) \\
\hline 10 & & Form Factor (Rf) & $\begin{array}{l}\mathrm{Rf}=\mathrm{A} / \mathrm{Lb}^{2} \\
\text { Where, } \\
\qquad \mathrm{Rf}=\text { form factor } \\
\\
\mathrm{A}=\text { area of the basin }\left(\mathrm{km}^{2}\right) \\
\mathrm{Lb}^{2}=\text { square of basin length }\end{array}$ & Horton (1932) \\
\hline 11 & & $\begin{array}{l}\text { Elongation Ratio } \\
\qquad(\mathrm{Re})\end{array}$ & $\begin{array}{l}\mathrm{Re}=2 \sqrt{ }(\mathrm{A} / \pi) / \mathrm{Lb} \\
\text { Where, } \quad \mathrm{Re}=\text { elongation ratio } \\
\qquad \mathrm{A}=\text { area of the basin }\left(\mathrm{km}^{2}\right) \\
\pi=\text { 'Pi' value }(3.142817) \\
\mathrm{Lb}=\text { basin length }\end{array}$ & Schumm (1956) \\
\hline 12 & & $\begin{array}{l}\text { Circularity Ratio } \\
\text { (Rc) }\end{array}$ & $\begin{array}{l}\mathrm{Rc}=4 * \pi^{*} \mathrm{~A} / \mathrm{P}^{2} \\
\text { Where, } \mathrm{Rc}=\text { circularity ratio } \\
\begin{aligned} \pi=\text { 'Pi' value }(3.142817) \\
\mathrm{A}=\text { area of the basin }\left(\mathrm{km}^{2}\right) \\
\quad \mathrm{P}^{2}=\text { square of perimeter }(\mathrm{km})\end{aligned}\end{array}$ & Miller (1953) \\
\hline 13 & & $\begin{array}{l}\text { Length of Overland } \\
\text { Flow (Lg) }\end{array}$ & $\begin{array}{l}\mathrm{Lg}=1 / \mathrm{Dd} * 2 \\
\text { Where, } \quad \mathrm{Lg}=\text { length of overland flow } \\
\mathrm{Dd}=\text { drainage density }\end{array}$ & Horton (1945) \\
\hline 14 & \multirow{3}{*}{$\begin{array}{c}\text { Relief } \\
\text { Aspects }\end{array}$} & $\begin{array}{l}\text { Watershed Relief } \\
\qquad(\mathrm{H})\end{array}$ & $\begin{array}{l}\text { vertical distance between the lowest and highest points of } \\
\text { watershed (highest - lowest) }\end{array}$ & Schumm (1956) \\
\hline 15 & & Relief Ratio (Rh) & $\begin{array}{l}\mathrm{Rh}=\mathrm{H} / \mathrm{Lb} \\
\text { Where, } \quad \mathrm{Rh}=\text { relief ratio } \\
\quad \mathrm{H}=\text { watershed relief } \\
\mathrm{Lb}=\text { basin length }\end{array}$ & Schumm (1956) \\
\hline 16 & & $\begin{array}{l}\text { Ruggedness Number } \\
\text { (Rn) }\end{array}$ & $\begin{array}{l}\mathrm{Rn}=\mathrm{H}^{*} \mathrm{Dd} \\
\text { Where, } \quad \mathrm{Rn}=\text { ruggedness number } \\
\quad \mathrm{H}=\text { watershed relief } \\
\mathrm{Dd}=\text { drainage density }\end{array}$ & Schumm (1956) \\
\hline
\end{tabular}




\section{Result and Discussion}

\subsection{Pattern of Drainage System}

The drainage pattern in the study arearelated withgeological characteristics and thefault directions, which stretched in two directions. The first direction: northwest-southeast in HuaiChomphu sub-watershed(1), Mae Yian sub-watershed(2) and Mae Tum sub-watershed(5). The second direction: northeast-southwestin Mae Puem sub-watershed(3), Mae Tam sub-watershed(6, Mae Tom sub-watershed(8, Mae Na Ruea sub-watershed(1), Mae Sai(1) and Mae Tham sub-watershed(12. Thefault directions affected to the stream positions, stream directions and drainage pattern in each sub-watersheds are shown in Figure 3. This result is conformed withTiyapairat and Mahabhum (1990) which reported the streams in Phayao province and Mae Chai district flow along the fault. In addition, Mae Tham sub-watershed which the faults have most diverse directions, as a result, the streams flow in this watershed are diverse as well.

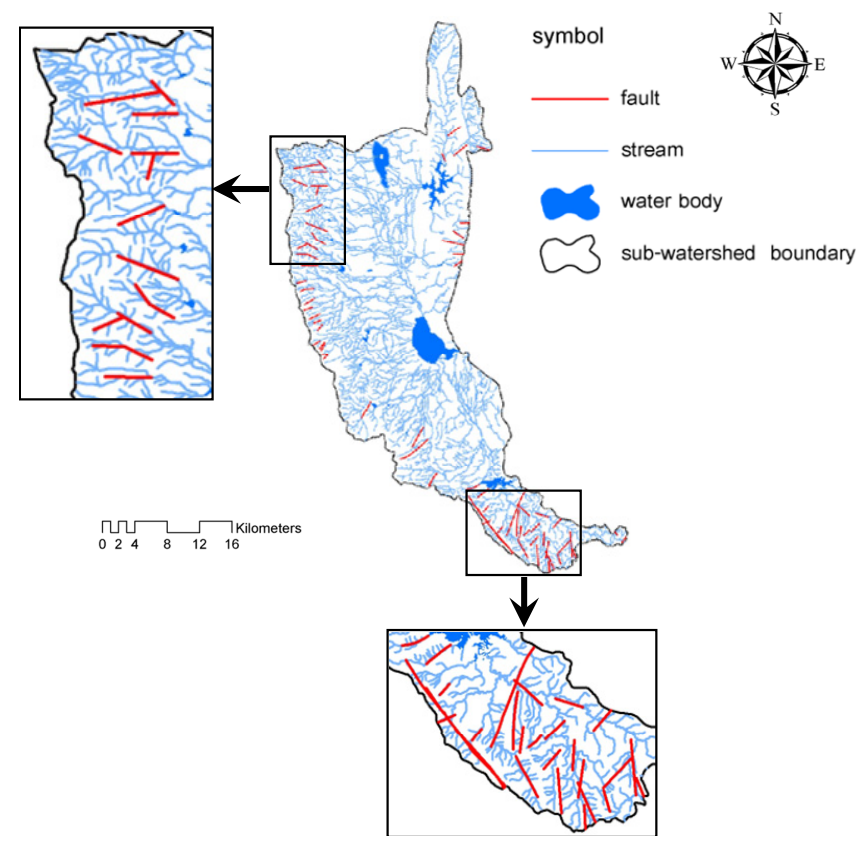

Figure 3. The relationship between streams and fault directions

The most of drainage patterns are dendritic drainage pattern which occur in every sub-watersheds as that shown in Table 2 and Figure 3. This pattern usually form in horizontal sedimentary or in intrusive igneous rocks where the rock mass is reasonably homogeneous, while the rectangular drainage pattern which tributaries confluence angles occurred along cracks and fault directions in northwestern areas in HuaiChomphu(1), Mae Yian(2), Mae Tum(5), Mae Tam(6), and occurred in southern area in Mae Tham sub-watershed(1). In addition, the trellis drainage pattern which the main streams are directed by the folded structures in syncline structural geology, whereas smaller streams are at work on adjacent slopes, joining the main stream at right angles (Selby, 1985). This drainage pattern occured in northeast areas in Mae Puem sub-watershed(3, which drainage patterns are controlled by rock structures of variable resistance, as shown in Table 2 and Figure 4.

Table 2. Drainage pattern of sub-watersheds in upper Ing watershed

\begin{tabular}{cll}
\hline No. & Sub-watersheds & Drainage pattern \\
\hline (1) & HuaiChomphu & Dendritic, Rectangular \\
(2) & Mae Yien & Dendritic, Rectangular \\
(3) & Mae Puem & Dendritic, Trellis \\
(4) & Huai Bong & Dendritic \\
(5) & Mae Tum & Dendritic, Rectangular \\
(6) & Mae Tam & Dendritic, Rectangular \\
(7) & HuaiLuek & Dendritic \\
(8) & Mae Tom & Dendritic \\
(9) & Mae Tun & Dendritic \\
(1) & Mae Na Ruea & Dendritic \\
(1) & Mae Sai & Dendritic \\
(1) & Mae Tham & Dendritic, Rectangular \\
\hline
\end{tabular}




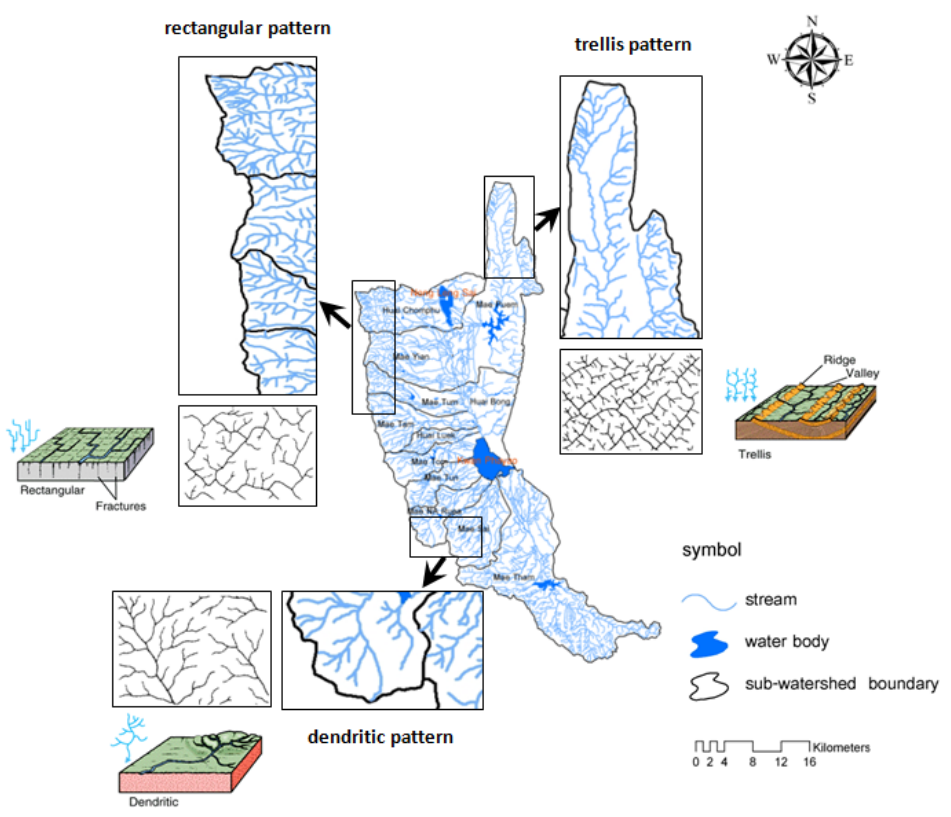

Figure 4. Drainage pattern existing in upper Ing watershed Source: Adapted some parts from Howard (1967)

\subsection{Drainage Morphology}

\section{1) Linear Aspect}

\section{a) Stream Number (Nu)}

The stream orders have been ranked according to Strahler's classification (1964). It was founded that most of the sub-watersheds formed the fourth order including Mae Yian(2), Mae Tum(5), Mae Tam(6), HuaiLuek(7), Mae Tom(8), Mae Tun(9) and Mae Na Ruea sub-watershed(10. The sub-watersheds formed the fifth orderincluding HuaiChomphu(1), Mae Puem(3), Mae Sai(1)andMae Tham sub-watershed(1), and lastly the sub-watershed are formed the third order was Huai Bong sub-watershed. When considering each order founded that the first order streams are most stream number while the fifth order streams are minimal stream number, as shown in Table 3. The result conformed with Strahler (1964), which described the total number of streams gradually decreases as the stream order increases. Morever, it is also found that Mae Tham sub-watershedhaving high values of first order streams which there is a possibility of sudden flash floods after heavy rainfall in the downstreams (Chitra et al., 2011).

\section{b) Stream Length (Lu)}

The stream length varies with the stream number in each stream orders that is the total length of stream segments is maximum in first order streams and decreases as the stream order increases (Horton, 1945). The result was founded that Mae Tham sub-watershed have most stream length in each orders, followed by Mae Puem, HuaiChomphu, Mae Yian and Mae Sai sub-watershedrespectively, which as shown in Table 3. This result demonstrated that the first order streams was short and situated in upstream area, conformed with Chitra et al. (2011) which indicated the streams with relatively short lengths are representative of areas with steep slopes and finer texture whereas longer lengths of stream are generally indicative of low gradients (Strahler, 1964).

\section{c) Mean Stream Length (Lsm)}

Mean Stream Length is inversed with the stream number and the stream length in each stream orders, that is the total stream number and the total length of stream segments which is maximum in first order streams was minimal in mean stream length as shown in Table 3. The result showed that the stream in first order was short line, difference with the next order which is longer than. Strahler (1964) indicated the Lsm is a characteristic property related to the size of drainage network components and its associated surfaces.

\section{d) Stream Length Ratio ( $R L)$}

Stream length ratio (RL) defined as the ratio of the mean length of the one order to the next lower order of the stream segments (Horton, 1945). The result showed the RL values exhibits an increasing trend from lower order 
to higher order including Huai Bong, Mae Tum, Mae Tam, Mae Tom, Mae Tun and Mae Na Ruea sub-watershed indicating the mature geomorphic stage. While the RL between streams of different order reveals that there is a variation in Huai Chomphu, Mae Yian, Mae Puem, Huai Luek, Mae Sai and Mae Tham sub-watershed indicating the late young geomorphic stage, as shown in Table 4. This variation might be attributed to variation in slope and topography (Magesh et al., 2012).

\section{e) Bifurcation Ratio (Rb) and Mean Bifurcation Ratio (Rbm)}

Bifurcation ratio $(\mathrm{Rb})$ defined as the ratio of the number of stream segments of given order to the number of segments of the next higher order (Schumm, 1956). Horton (1945) considered the Rb as an index of relief and dissections. The result showed that Mae Tum sub-watershed have the highest Rbm values (4.28), whileMae Sai sub-watershed have the lowest Rbm values (2.94), as shown in Table 4. The result conformed with Strahler (1957) who indicated $\mathrm{Rb}$ values characteristically range between 3.0 and 6.0 for watersheds in which the geologic structures do not distort the drainage pattern. The sub-watersheds which high Rb values including Mae Tum, Mae Tam, Mae Tham and Mae Tun sub-watershed expected in regions of steeply dipping rock strata, elongated basins and low but extended peak flow, while rounded basins with low ratio produce a sharp peak (Chitra et al., 2011).

Table 3. Linear aspect characteristics of sub-watersheds in upper Ing watershed (1)

\begin{tabular}{|c|c|c|c|c|c|c|c|c|c|c|c|c|c|c|c|c|c|c|}
\hline \multirow[t]{2}{*}{ No. } & \multirow{2}{*}{$\begin{array}{l}\text { sub-watershe } \\
\text { dname }\end{array}$} & \multirow[t]{2}{*}{ order } & \multirow{2}{*}{$\begin{array}{l}\text { Basin } \\
\text { Area } \\
\left(\mathbf{k m}^{2}\right) \\
\end{array}$} & \multicolumn{5}{|c|}{$\begin{array}{c}\text { Stream number in order } \\
(\mathrm{Nu})\end{array}$} & \multicolumn{5}{|c|}{$\begin{array}{c}\text { Stream Length (Lu) } \\
(\mathbf{k m}) \\
\end{array}$} & \multicolumn{5}{|c|}{ Mean Stream Length (Lsm) (km) } \\
\hline & & & & $\mathbf{I}$ & II & III & IV & $\mathbf{V}$ & I & II & III & IV & $\mathbf{V}$ & $\mathbf{I}$ & II & III & IV & $\mathbf{V}$ \\
\hline 1 & HuaiChomphu & 5 & 111.96 & 129 & 26 & 5 & 2 & - & 103.5 & 42.1 & 38.7 & 11.4 & 7.7 & 0.8 & 1.6 & 7.8 & 5.7 & 7.7 \\
\hline 2 & Mae Yian & 4 & 95.74 & 92 & 15 & 5 & 2 & - & 100.9 & 22.0 & 37.7 & 25.1 & - & 1.1 & 1.5 & 7.6 & 12.6 & - \\
\hline 3 & Mae Puem & 5 & 215.83 & 128 & 36 & 5 & 2 & 1 & 129.5 & 47.8 & 27.5 & 11.5 & 38.5 & 1.0 & 1.3 & 5.5 & 5.7 & 38.5 \\
\hline 4 & Huai Bong & 3 & 70.60 & 35 & 7 & 2 & - & - & 40.4 & 20.5 & 13.6 & - & - & 1.2 & 2.9 & 6.8 & - & - \\
\hline 5 & Mae Tum & 4 & 52.87 & 57 & 9 & 2 & 1 & - & 59.2 & 19.5 & 8.1 & 10.8 & - & 1.0 & 2.2 & 4.1 & 10.8 & - \\
\hline 6 & Mae Tam & 4 & 67.68 & 70 & 15 & 5 & 1 & - & 64.2 & 23.5 & 15.6 & 29.4 & - & 0.9 & 1.6 & 3.1 & 29.4 & - \\
\hline 7 & HuaiLuek & 4 & 23.24 & 32 & 10 & 2 & 1 & - & 21.4 & 10.4 & 16.4 & 3.5 & - & 0.7 & 1.0 & 8.2 & 3.5 & - \\
\hline 8 & Mae Tom & 4 & 50.78 & 41 & 12 & 3 & 1 & - & 57.5 & 15.5 & 4.4 & 21.0 & - & 1.4 & 1.3 & 1.5 & 21.0 & - \\
\hline 9 & Mae Tun & 4 & 43.38 & 50 & 13 & 2 & 1 & - & 46.8 & 14.4 & 7.5 & 25.1 & - & 0.9 & 1.1 & 3.8 & 25.1 & - \\
\hline 10 & Mae Na Ruea & 4 & 52.41 & 48 & 16 & 5 & 1 & - & 46.2 & 19.1 & 9.3 & 26.2 & - & 1.0 & 1.2 & 1.9 & 26.2 & - \\
\hline 11 & Mae Sai & 5 & 79.51 & 68 & 18 & 6 & 3 & 1 & 67.1 & 40.7 & 19.7 & 19.2 & 11.9 & 1.0 & 2.3 & 3.3 & 6.4 & 11.9 \\
\hline 12 & Mae Tham & 5 & 267.31 & 290 & 57 & 14 & 4 & 1 & 256.6 & 107.6 & 86.6 & 14.7 & 80.0 & 0.9 & 1.9 & 6.2 & 3.7 & 80.0 \\
\hline
\end{tabular}

Table 4. Linear aspect characteristics of sub-watersheds in upper Ing watershed (2)

\begin{tabular}{|c|c|c|c|c|c|c|c|c|c|c|c|c|}
\hline \multirow{2}{*}{ No. } & \multirow{2}{*}{$\begin{array}{l}\text { sub-watershed } \\
\text { name }\end{array}$} & \multirow{2}{*}{$\begin{array}{c}\text { Basin } \\
\text { Length } \\
(\mathrm{km})\end{array}$} & \multirow{2}{*}{$\begin{array}{l}\text { Perimeter } \\
\text { (km) }\end{array}$} & \multicolumn{4}{|c|}{ Stream Length Ratio (RL) } & \multicolumn{4}{|c|}{ Bifurcation Ratio (Rb) } & \multirow{2}{*}{$\begin{array}{c}\text { Mean } \\
\text { Bifurcation } \\
\text { Ratio (Rbm) }\end{array}$} \\
\hline & & & & II/I & III/II & IV/III & V/IV & $\mathbf{I} / \mathbf{I I}$ & II/III & III/IV & IV/V & \\
\hline 1 & HuaiChomphu & 19.79 & 54.69 & 0.41 & 0.92 & 0.29 & 0.68 & 4.96 & 5.20 & 2.50 & 2.00 & 3.67 \\
\hline 2 & Mae Yian & 14.96 & 47.87 & 0.22 & 1.71 & 0.67 & - & 6.13 & 3.00 & 2.50 & - & 3.88 \\
\hline 3 & Mae Puem & 31.13 & 91.65 & 0.37 & 0.57 & 0.42 & 3.35 & 3.56 & 7.20 & 2.50 & 2.00 & 3.81 \\
\hline 4 & Huai Bong & 9.14 & 46.02 & 0.51 & 0.66 & - & - & 5.00 & 3.50 & - & - & 4.25 \\
\hline 5 & Mae Tum & 16.83 & 42.53 & 0.33 & 0.42 & 1.33 & - & 6.33 & 4.50 & 2.00 & - & 4.28 \\
\hline 6 & Mae Tam & 17.24 & 46.63 & 0.37 & 0.66 & 1.89 & - & 4.67 & 3.00 & 5.00 & - & 4.22 \\
\hline 7 & HuaiLuek & 12.72 & 30.27 & 0.49 & 1.57 & 0.21 & - & 3.20 & 5.00 & 2.00 & - & 3.40 \\
\hline 8 & Mae Tom & 15.40 & 41.96 & 0.27 & 0.28 & 4.81 & - & 3.42 & 4.00 & 3.00 & - & 3.47 \\
\hline 9 & Mae Tun & 12.23 & 35.88 & 0.31 & 0.52 & 3.34 & - & 3.85 & 6.50 & 2.00 & - & 4.12 \\
\hline 10 & Mae Na Ruea & 14.22 & 41.95 & 0.41 & 0.49 & 2.81 & - & 3.00 & 3.20 & 5.00 & - & 3.73 \\
\hline 11 & Mae Sai & 14.46 & 41.26 & 0.61 & 0.48 & 0.97 & 0.62 & 3.78 & 3.00 & 2.00 & 3.00 & 2.94 \\
\hline 12 & Mae Tham & 34.35 & 119.21 & 0.42 & 0.80 & 0.17 & 5.45 & 5.09 & 4.07 & 3.50 & 4.00 & 4.16 \\
\hline
\end{tabular}

\section{2) Areal Aspect}

\section{a) Drainage Density (Dd)}

Drainage density (Dd) is defined as the total length of streams of all order per drainage area, this values indicates the closeness of spacing of channels (Horton, 1932). This factor is related to climate, type of rocks, relief, infiltration capacity, vegetation cover and runoff intensity index, which the low Dd values occur where basin relief is low while high Dd is favoured where basin relief is high (Strahler, 1964). The result showed that Huai 
Luek sub-watershed had the highest Dd value (2.22), while Huai Bong sub-watershedhad the lowest Dd value (1.06), as shown in Table 5. The result indicated whole sub-watersheds had Dd values in moderate level (Dd value between 1-5) (Chunkao, 2008).

\section{b) Drainage Texture (Rt)}

Drainage texture (Rt) is the total number of stream segments of all orders per perimeter of that area (Horton, 1945). The Rt value depends upon a number of natural factors such as climate, rainfall, vegetation, rock and soil type, infiltration capacity, relief and stage of development (Smith, 1950). The result was founded that Mae Tham sub-watershedwas the highest Rt value (3.07), while Huai Bong sub-watershedwas the lowest Rt value (0.96), as shown in Table 5. According to Smith's classification, it could be notified that every sub-watersheds have a course drainage texture (Smith, 1950).

\section{c) Stream Frequency ( $F s$ )}

Stream frequency (Fs) is the ratio of the total number of stream segments of all the orders in the watershed to the total area of the watershed (Horton, 1932). The result showed that Huai Luek sub-watershed was the highest Fs value (1.94), while Huai Bong sub-watershedwas the lowest Fs value (0.62), as shown in Table 5. The Fs value exhibit positive correlation with the drainage density and related to permeability, infiltration capacity and relief of sub-watershed (Chitra et al., 2011), conformed with the physiographic of Huai Bong sub-watershed which has high relief, highly permeable and dense vegetation .

\section{d) Form Factor (Rf)}

Form factor (Rf) is defined as the ratio of the watershed area to the square of the watershed length. This factor related to stream flow and shape of watershed (Zende \& Nagrajan, 2011). The result indicated thatHuai Bong sub-watershedhad the highest $\mathrm{Rf}$ value (0.85), while HuaiLuek sub-watershed was the lowest Rf value $(0.19)$, as shown in Table 5. Corresponded with Magesh et al. (2012), the Rf value should always be less than 0.7854 which the value corresponding to a perfectly circular basin and found that only Huai Bong sub-watershedhad Rf value more than Magesh's value. The elongated watershed with low value of Rf indicates that the watershed will have a flatter peak flow for longer duration (Chitra et al., 2011).

\section{e) Elongation Ratio (Re)}

Elongation ratio $(\mathrm{Re})$ is the ratio between the diameter of a circle of the same area as the drainage basin and the maximum watershed length (Schumm, 1956). The value of Re generally vary from 0.6 to 1.0 over a wide variety of climate and geologic types, and if Re value close to 1.0 are typical of regions of very low relief (Strahler, 1964). These values can be grouped into four categories namely (a) circle ( $>0.9$ ), (b) oval (0.9 to 0.8) (c) less elongated $(<0.7)$ and $(d)$ elongated $(>0.7)$. The result from this study showed that Huai Bong sub-watershedwas highestRe value (1.04) indicated a circle shape, the second was Mae Yian sub-watershed (0.74) indicated elongated shape, while Huai Luek sub-watershed had the lowest Re value (0.43) indicated less elongated shape too, as shown in Table 5. Furthermore, Huai Chomphu, Mae Tun, Mae Sai and Mae Yian sub-watershed had Re value between $0.6-0.8$, conformed withStrahler (1964) defined where as values in the range 0.6 to 0.8 are usually associated with high relief and steep ground slope.

\section{f) Circularity Ratio (Rc)}

Circularity ratio $(\mathrm{Rc})$ is the ratio of the area of a basin to the area of a circle having the same circumference as the perimeter of the watershed. Miller (1953) indicated the Rc value range 0.4 to 0.5 which strongly elongated and highly permeable homogenous geologic materials. The result showed that the majority of the sub-watersheds had Rc value $<0.5$, indicating elongate shape, while Mae Sai sub-watershed and Mae Yian sub-watershed had Rc value $>0.5$, indicating circle shape. In addition, Miller (1953) described Rc is a significant ratio that indicates the dendritic stage of a watershed. The sub-watershed which had low Rc value, including Mae Tham (0.24), Mae Puem (0.32) and Huai Luek (0.32), indicated young geomorphic stage, while the sub-watershed which had high Rc value, including Mae Sai (0.59), Mae Yian (0.53) and Huai Chomphu (0.47), indicated mature geomorphic stage, as shown in Table 5.

\section{g) Length of Overland Flow ( $\mathrm{Lg}$ )}

Length of overlandflow $(\mathrm{Lg})$ is defined as the length of the longest drainage path that water takes before it gets concentrated (Horton, 1945). The result was founded that Huai Bong sub-watershed was the highest Lg value (0.47), while Huai Luek and Mae Tun sub-watershed was the lowest Lg value (0.23), which as shown in Table 5. The result indicated by Chitra et al. (2011) that the sub-watershed which was high Lg value, such as Huai Bong, the rainwater had to travel relatively longer distance before getting concentrated into stream channels. This 
feature difference with the sub-watershed which had low Lg value, such as Mae Tun, the rainwater will enter the stream quickly.

Table 5. Areal aspect characteristics of sub-watersheds in upper Ing watershed

\begin{tabular}{|c|c|c|c|c|c|c|c|c|}
\hline No. & $\begin{array}{c}\text { sub-watershedsna } \\
\text { me }\end{array}$ & $\begin{array}{c}\text { Drainage } \\
\text { Density } \\
\text { (Dd) }\end{array}$ & $\begin{array}{c}\text { Drainage } \\
\text { Texture } \\
\text { (Rt) }\end{array}$ & $\begin{array}{c}\text { Stream } \\
\text { Frequency } \\
\text { (Fs) }\end{array}$ & $\begin{array}{c}\text { Form } \\
\text { Factor } \\
\text { (Rf) }\end{array}$ & $\begin{array}{c}\text { Elongation } \\
\text { Ratio } \\
(\mathbf{R e}) \\
\end{array}$ & $\begin{array}{c}\text { Circularity } \\
\text { Ratio } \\
\text { (Rc) }\end{array}$ & $\begin{array}{c}\text { Length of } \\
\text { overlandflow } \\
\text { (Lg) }\end{array}$ \\
\hline 1 & HuaiChomphu & 1.82 & 2.98 & 1.46 & 0.29 & 0.60 & 0.47 & 0.28 \\
\hline 2 & Mae Yian & 1.94 & 2.38 & 1.19 & 0.43 & 0.74 & 0.53 & 0.26 \\
\hline 3 & Mae Puem & 1.18 & 1.88 & 0.80 & 0.22 & 0.53 & 0.32 & 0.42 \\
\hline 4 & Huai Bong & 1.06 & 0.96 & 0.62 & 0.85 & 1.04 & 0.42 & 0.47 \\
\hline 5 & Mae Tum & 1.85 & 1.62 & 1.31 & 0.19 & 0.49 & 0.37 & 0.27 \\
\hline 6 & Mae Tam & 1.96 & 1.95 & 1.34 & 0.23 & 0.54 & 0.39 & 0.26 \\
\hline 7 & HuaiLuek & 2.22 & 1.49 & 1.94 & 0.14 & 0.43 & 0.32 & 0.23 \\
\hline 8 & Mae Tom & 1.94 & 1.36 & 1.12 & 0.21 & 0.52 & 0.36 & 0.26 \\
\hline 9 & Mae Tun & 2.16 & 1.84 & 1.52 & 0.29 & 0.61 & 0.42 & 0.23 \\
\hline 10 & Mae Na Ruea & 1.92 & 1.67 & 1.34 & 0.26 & 0.57 & 0.37 & 0.26 \\
\hline 11 & Mae Sai & 1.99 & 2.33 & 1.21 & 0.38 & 0.70 & 0.59 & 0.25 \\
\hline 12 & Mae Tham & 2.04 & 3.07 & 1.37 & 0.23 & 0.54 & 0.24 & 0.25 \\
\hline
\end{tabular}

\section{3) Relief Aspect}

\section{a) Watershed Relief (H)}

Watershed relief $(\mathrm{H})$ is the maximum vertical difference between the lowest and the highest point of a watershed. The high relief value indicates the gravity of water flow, low infiltration and high runoff conditions (Magesh et al., 2012). The result showed that the sub-watershed which high $\mathrm{H}$ value, including Mae Tun (1.28 km), Mae Tom $(1.20 \mathrm{~km})$, and Mae Tam $(1.06 \mathrm{~km})$, indicated the gravity of water flow, low infiltration and high run off conditions. Differences with Huai Bong sub-watershed, which low $\mathrm{H}$ value $(0.28 \mathrm{~km})$, indicated the less gravity of water flow, high infiltration and low runoff conditions, as shown in Table 6.

\section{b) Relief Ratio (Rh)}

Relief ratio $(\mathrm{Rh})$ is defined as the horizontal distance along the longest dimension of the watershed parallel to the principal drainage line (Schumm, 1956). Rh indicating the overall steepness of a drainage basin and it an indicator of intensity of erosion processes operating on the slope of the watershed (Magesh et al., 2012). The result was founded that the $\mathrm{Rh}$ value of each sub-watershed is not different, as shown in Table 6. The sub-watersheds having high Rh values are Mae Tun (0.10) and Mae Na Ruea (0.07), may indicated steep slope and high relief, while the lower values was found at Mae Puem (0.02) and Huai Luek (0.02).

\section{c) Ruggedness Number (Rn)}

Ruggedness Number $(\mathrm{Rn})$ is defined as the ratio between the watershed relief and the drainage density. If the $\mathrm{Rn}$ value is higher, the peak discharge rates are likely to be higher and indicated the watershed is susceptible to erosion (Chitra et al., 2011). The result was founded that the sub-watershed which high Rn values, including Mae Tun (2.77), Mae Tom (2.33), and Mae Tam (2.08) as shown in Table 6, may indicatedthe peak discharge rates are likely to be higher and susceptible to erosion. While Huai Bong sub-watershed which lowest Rn values, may indicated the peak discharge rates are likely to be less and low erosion. 
Table 6. Relief aspect characteristics of sub-watersheds in upper Ing watershed

\begin{tabular}{ccccc}
\hline No. & $\begin{array}{c}\text { sub-watershedsna } \\
\text { me }\end{array}$ & $\begin{array}{c}\text { Watershed Relief }(\mathbf{H}) \\
(\mathbf{k m})\end{array}$ & $\begin{array}{c}\text { Relief Ratio } \\
(\mathbf{R h})\end{array}$ & $\begin{array}{c}\text { Ruggedness } \\
\text { Number }(\mathbf{R n})\end{array}$ \\
\hline 1 & HuaiChomphu & 1.00 & 0.05 & 1.82 \\
2 & Mae Yian & 0.86 & 0.06 & 1.67 \\
3 & Mae Puem & 0.52 & 0.02 & 0.61 \\
4 & Huai Bong & 0.28 & 0.03 & 0.30 \\
5 & Mae Tum & 1.00 & 0.06 & 1.84 \\
6 & Mae Tam & 1.06 & 0.06 & 2.08 \\
7 & HuaiLuek & 0.28 & 0.02 & 0.62 \\
8 & Mae Tom & 1.20 & 0.08 & 2.33 \\
9 & Mae Tun & 1.28 & 0.10 & 2.77 \\
10 & Mae Na Ruea & 1.02 & 0.07 & 1.96 \\
11 & Mae Sai & 0.68 & 0.05 & 1.36 \\
12 & Mae Tham & 0.86 & 0.03 & 1.75 \\
\hline
\end{tabular}

\subsection{Drainage Morphometric Parameters of Drainage Patterns}

The drainage morphometric parameters of the study area can be described as follows:

\section{1) Dendritic Drainage Pattern}

The dendritic drainage pattern is the most common form of drainage system. There are many contributing streams (analogous to the twigs of a tree), which are then joined together into the tributaries of the main river. They develop where the river channel follows the slope of the terrain (Lambert, 1998).

The dendritic drainage pattern occurs in all sub-watersheds which can be classified into two features. The first was the high-altitude dendritic drainage pattern, which situated in upstream including the most parts of Huai Luek(7), Mae Tom(8), Mae Tun(9, Mae Na Ruea(1) and Mae Sai sub-watershed(11. The second was the low-altitude dendritic drainage pattern, which situated in lower terrace and plain including the most parts of Huai Bong sub-watershed (4, moreover the dendritic drainage pattern occurred in the lowest area of Mae Tham sub-watersheds (11).

\section{a) The High-altitude Dendritic Drainage Pattern}

The result showed that the high-altitude dendritic drainage pattern had stream length ratio values (RL) exhibits an increasing trend from lower order to higher order, which indicated the mature geomorphic stage (Magesh et al., 2012). Bifurcation ratio values $(\mathrm{Rb})$ and mean bifurcation ratio $(\mathrm{Rbm})$ in this area were low, indicated moderate steep slopes which moderated discharge of runoff. The drainage density value (Dd) and stream frequency (Fs) in this area was high, while the drainage texture (Rt) were moderated, implying this area situated in undulating, rolling phase, and upper terrace. In addition, the watershed relief $(\mathrm{H})$ and the ruggedness number $(\mathrm{Rn})$ were relatively high, indicating high discharge of runoff.

The high-altitude dendritic drainage pattern affected by physiographical features of the watershed in undulating, rolling phase and upper terrace, which situated between the western highland and the plain which tectonic forces collapsed along the fault and formed a large graben.

\section{b) The Low-altitude Dendritic Drainage Pattern}

In the area of the low-altitude dendritic drainage pattern had RL values exhibits an increasing trend from lower order to higher order, which indicated the mature geomorphic stage similarly the high-altitude dendritic drainage pattern.The $\mathrm{Rb}$ and $\mathrm{Rbm}$ values in this area were high, which indicated less slopes. The $\mathrm{Dd}$, Rt and Fs values in this area was low, implying that this area situated in lower terrace and plain. The low-altitude dendritic drainage pattern, had lowest $\mathrm{H}$ and $\mathrm{Rn}$ value, indicated the peak discharge rates were likely to be less, high infiltration, low discharge of runoff and lightly erosion processes.In addition, the form factor value (Rf) of this drainage pattern was higher than the others, which indicatedits was a circular watershed. Lastly, the low-altitude dendritic drainage pattern founded in the fifth stream order in some sub-watersheds which the length of a fifth stream order was long because the runoff meandering and branching into several sub-streams before flowing into the Kwan Phayao, this landform occurred in the plains nearby the outlet of watershed in Mae Tham sub-watershed. 
The rectangular drainage developed on rocks that are of approximately uniform resistance to erosion, but which have two directions of jointing at approximately right angles (Ritter, 2006).

The rectangular drainage pattern occurs in the high-altitude parts of Huai Chomphu(1), Mae Yian(2), Mae Tum(5), Mae Tam(6) and Mae Tham sub-watersheds(1), which the faults appeared. The result showed that RL values between streams of different order revealed a variation, which indicating the late young geomorphic stage because this area were varied in slope and topography (Magesh et al., 2012). The Rb and Rbm values in this area were moderated, which expected in regions of steeply dipping rock strata, elongated basins and low but extended peak flow, while rounded basins with low ratio produce a sharp peak (Chitra et al., 2011). The Dd, Rt and Fs values in this area was high, implying this area situated in upper terrace and highland. In addition, the $\mathrm{H}$ and $\mathrm{Rn}$ values were highly than other drainage pattern, indicating the high discharge of runoff and highly erosion processes and indicated the presence of basement rocks that are exposed in the form of small ridges and mounds with lower degree of slope (Chitra et al., 2011).

\section{3) Trellis Drainage Pattern}

The geometry of a trellis drainage system is similar to that of a common garden trellis used to grow vines. As the river flows along a strike valley, smaller tributaries feed into it from the steep slopes on the sides of mountains. These tributaries enter the main river at approximately 90 degree angles, causing a trellis-like appearance of the drainage system and trellis drainage is characteristic of folded mountains (Ritter, 2006).

The trellis drainage pattern occurs in only Mae Puem sub-watershed(3), which the rock layers bend or tilt in syncline structural geology. The result showed that RL values exhibits an increasing trend from lower order to higher order, which indicated the mature geomorphic stage. Secondly, the $\mathrm{Rb}$ and $\mathrm{Rbm}$ values in this area were moderated, indicated high steeply slopes which extended peak flow and high discharge of runoff. The Dd, Rt and Fs values in this area are moderated, implied this area situated in upper terrace and highland. In addition, the $\mathrm{H}$ and $\mathrm{Rn}$ values are moderated, indicated the moderated discharge of runoff and intermediate erosion processes. The trellis drainage pattern had moderated in the $\mathrm{H}$ and $\mathrm{Rn}$ values, indicated moderated discharge of runoff as well.

The tectonic forces collapsed the northeast upland into syncline structural geology, which formed the trellis drainage pattern.Furthermore, the form factor (Rf), elongation ratio $(R e)$ and circularity ratio $(R c)$ are a parameters demonstrated the shapes of watersheds, its not shown the characteristics of drainage patterns, which the relationship between drainage patterns and drainage morphological parameters as shown in the Table 7 .

Table 7. Relief aspect characteristics of sub-watersheds in upper Ing watershed

\begin{tabular}{lccccccccc}
\hline \multirow{2}{*}{ Drainage patterns } & \multicolumn{1}{c}{$\begin{array}{c}\text { Linear } \\
\text { aspects }\end{array}$} & \multicolumn{4}{c}{ Areal aspects } & & \multicolumn{2}{c}{ Relief aspects } \\
\cline { 2 - 10 } & Rbm & Dd & Rt & Fs & Rf & Lg & H & Rn \\
\hline Dendritic & & & & & & & & \\
- high-altitude & L & H & M & H & M & L & H & H \\
- low-altitude & H & L & L & L & H & H & L & L \\
\hline Rectangular & M & H & H & H & M & L & H & H \\
\hline Trellis & M & M & M & M & M & H & M & M \\
\hline
\end{tabular}

Note: $\mathrm{H}=$ High value, $\mathrm{M}=$ Moderate value, $\mathrm{L}=$ Low value

\subsection{Geological Structural Control on Drainage Morphology}

Three distinctive drainage patterns can be synthesized based on the geological formation and structure, they are:

\section{1) Dendritic Drainage Pattern}

Two distinctive areas of dendritic pattern can be found, the highland and lowland. The high-altitude dendritic drainage pattern including 5 sub-watersheds formed in V-shaped valleys where the rock types are impervious and non-porous. The geological structures of this areas on the upland consisted of granite, shale, sandstone, and on the lowland formed on the terrace and alluvial fan sand, gravel bed and colluvial clay formation, which this feature are described by Figure 5, A. 
The high-altitude dendritic drainage pattern have been influenced by sedimentary structure that a stream branches flowed not exactly in the direction that the rocks was hard or horizontal position or a same densed rock textures and the equal slope. The characteristics of such rock's types affected to the texture of the drainage pattern. A dense drainage pattern occurred in shale which has a fine-grained and weaker and less competent than granite and sandstone, then shale is less resistant to erosion than granite and sandstone. While a coarse drainage pattern occurred in granite and sandstone which is more resistant to erosion than shale.

The low-altitude dendritic drainage pattern existed only 1 sub-watershed (4). The geological structures of this area consisted of fluvial clay and sand formation, and found swampy clay and peat formation in somewhere. These structures affected to stream meandering in mature geomorphic stage.

The low-altitude dendritic drainage pattern has been influenced by sedimentary structure that is the most common form of drainage system. They develop where the river channel follows the slope of the terrain in areas of uniform rock, with little distortion by folding or faulting, the rivers develop a random branching network similar to a tree. The fluvial clay and sand formation in this lowland area affected a fine drainage pattern and influence a stream meandering and branching into several sub-streams before flowing into the Kwan Phayao wetland. It could be said that the sedimentary structure caused both the high-altitude and the low-altitude dendritic drainage patterns.

\section{2) Rectangular Drainage Pattern}

The rectangular drainage pattern appears in 5 sub-watersheds formed in V-shaped valleys similarly the high-altitude dendritic drainage pattern, which occurred above the multi-directional fault structures. The geological structures consisted of shale, sandstone, terrace sand and gravel bed formation (Figure 5, B).

One can see that, the tectonic structure caused the rectangular drainage pattern in northwest-west area of the watershed. This drainage pattern occurred in areas of various rocks, with little distortion by folding. The faults and joints are usually less resistant to erosion than the bulk rock, so erosion tends to preferentially open the joints and streams eventually develop along the joints. The result is a stream system in which streams consist mainly of straight line segments with right angle bends and tributaries join larger streams at right angles.

In this area, the properties of such rock's types affected to a dense or coarse drainage pattern. A dense drainage pattern occurred in shale which has a fine-grained texture, while a coarse drainage pattern occurred in sandstone which has a coarse-grained texture. Furthermore, the properties of such sandstone's types also affected to a dense or coarse drainage pattern, that is a dense drainage pattern occurred in older sandstone which has a fine-grained texture, while a coarse drainage pattern occurred in younger sandstone which has a coarse-grained texture. It could be said that the tectonic structure caused the rectangular drainage pattern in this study area

\section{3) Trellis Drainage Pattern}

The trellis drainage pattern in this study occurs only 1 sub-watershed(3) and formed in syncline structure, which occurred in northeastern area. The geological structures of this areas consisted of newer shale in the lower areas and sandstone in the higher area around a collapsed graben. This feature occurred in moderated altitude upland and underlied with bending rocks, as shown in Figure 5, C.

The sedimentary structure folding by tectonic force caused the trellis drainage pattern in northeast area of the watershed. The basin shapes are like round synclines, with the youngest strata exposed in the core. Mae Puem's syncline (3) are folds with the sedimentary strata (sandstone) dipping toward the axis of the structure and the youngest strata (shale) exposed in the core. In this area, the sandstone layers will stand out prominently around syncline structure, while the shale layers will appear indented, almost hidden, and beneath in a lower area of syncline structure. Shale is a very fissile rock that will readily fragment, while sandstone is typically made of quartz grains that are moderately to well cemented together and is resistant to normal weathering processes. Thus, the types of drainage pattern do not have influence by the rock's types, but the rock's types determine a dense or coarse drainage pattern in this area. It could be said that the tectonic structure and the sedimentary structure are influenced by tectonic force which consequently caused the trellis drainage pattern. 


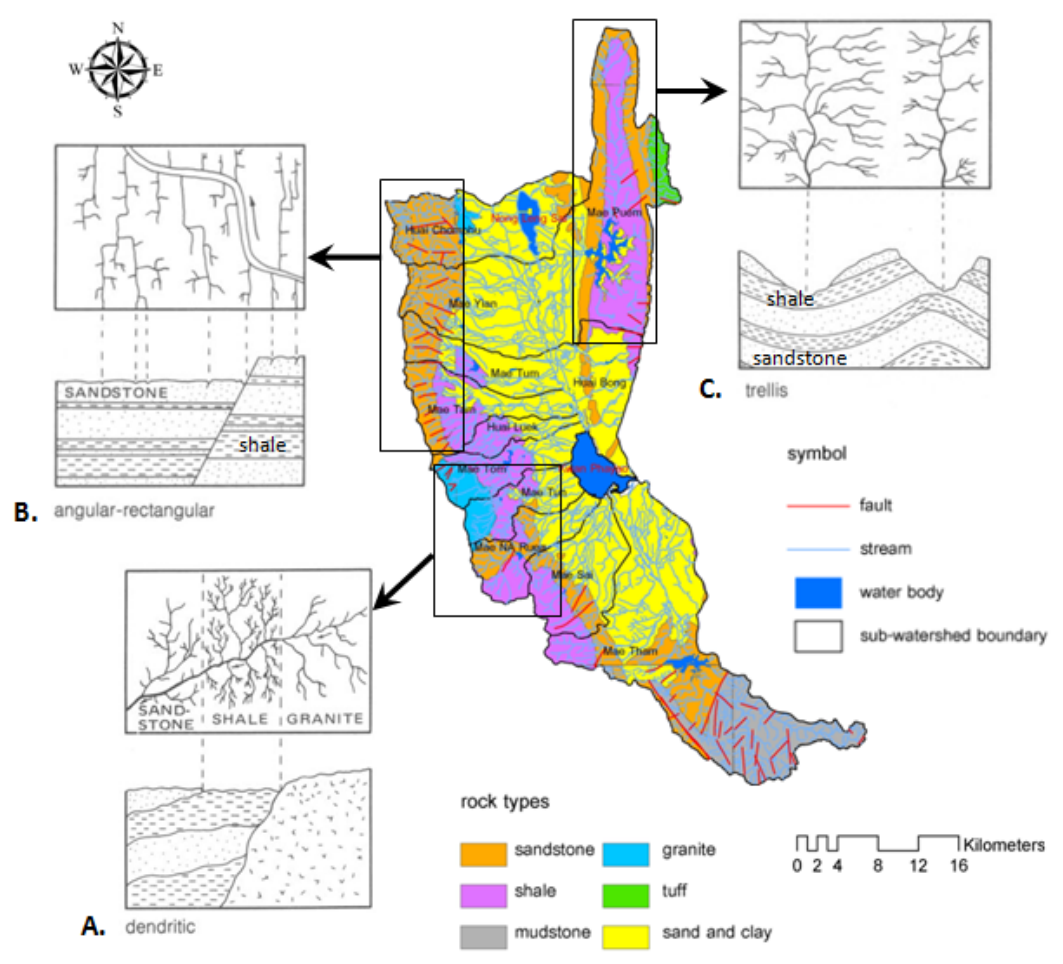

Figure 5. The geological structure of drainage patterns occurred in study area Source: Adapted some parts from Howard (1967)

Furthermore, the difference of drainage patterns has affected to the power of stream flow. The dendritic drainage pattern which minor streams flowed confluent to major stream in angulary angle. This feature affected stream flow not so severe, less inundation and water spreading not far from the main stream. While the rectangular drainage pattern and the trellis drainage pattern, which minor streams flowed confluent to major stream in right angle. This feature affected stream flow was severe, highly inundation, and water spreading was far from the main stream. However, the difference between rectangular and the trellis drainage pattern were persistence, because the rectangular pattern occurred in the higher altitude than the trellis pattern. Then the gravity of water flow was higher than the trellis pattern, which concluded the rectangular drainage pattern was maximum in stream flow power. These features could be described by Figure 6 .

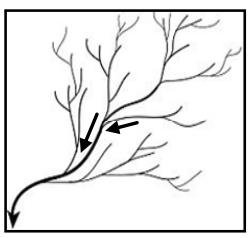

Dendritic

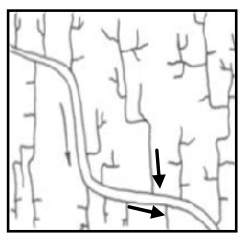

Rectangular

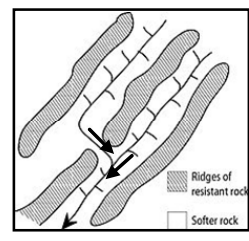

Trellis

Figure 6. The stream flow direction and power in relation to drainage patterns

Source: Adapted some parts from Howard (1967) and Ritter (2006)

\section{Conclusion}

According to the result of this study, it was demonstrated that the drainage patterns correlated to geological structures and directions of fault. Most of areas were dendritic drainage pattern, which occured in plain, the rectangular drainage pattern was also founded in fault areas, while the trellis drainage pattern occurred in syncline structural geology in northeast area in Mae Puem sub-watershed.

The drainage morphology was analyzed by GIS and calculated 16 parameters in 3 aspects including linear aspect, areal aspect and relief aspect. It was founded that watershed morphology has been controlled by physiography and graben structure. The highland formed in western area and lower to Kwan Phayao which the lowest part of 
graben, this feature caused the streams runoff more rapidly into the lower areas, affected low permeability and high erosion especially in the western sub-watersheds. On the other hand, the relief aspect of watershed redounded to slow runoff on slopes as well as high permeability and low erosion, which the calculated drainage morphometric parameters showed the result according to their appearances. The result of this study could be applied to watershed management in order to understand the hydrological characteristics of upper Ing involving peak flow of streams, permeable capacity, drainage capacity as well as erosion rate

\section{Acknowledgement}

The authors wish to thank Professor Dr. Mondhon Sanguansermsri, President of University of Phayao and Professor Dr. Kasem Chunkao, College of Environment, Kasetsart University for supported my doctoral studies. Thanks to Office of the Higher Education Commission, Ministry of Education, Thailand for the doctoral scholarship.

\section{References}

Chitra, C., Alaguraja, P., Ganeshkumari, K., Yuvaraj, D., \& Manivel, M. (2011). Watershed characteristics of Kundahsubbasin using remote sensing and GIS techniques. International Journal of geomatics and geosciences, 2(1), 311-335.

Chopra, R. (2005). Morphometric analysis of sub-watersheds in Gurdaspur district, Punjab using remote sensing and GIS techniques. Journal of the Indian Society of Remote Sensing, 33(4), 531-539. http://dx.doi.org/10.1007/BF02990738

Chunkao, K. (2008). Principles of Watershed Management. Kasetsart University Press, Bangkok. p.341

Horton, R. E. (1932). Drainage basin characteristics. Transactions of American Geophysics Union, 13, 350-361.

Horton, R. E. (1945). Erosional development of streams and their drainage basins; Hydrophysical approach to quantitative morphology. Bulletin of Geological Society of America, 56, 275-370.

Howard, A. D. (1967). Drainage analysis in geologic interpretation. The American Association of Petroleum Geologists, 51(11), 2246-2259.

Lambert, D. (1998). The Field Guide to Geology. pp. 130-131. Checkmark Books.

Magesh, N. S., Jitheshlal, K. V., \& Chandrasekar, N. (2012). GIS based morphometric evaluation of Chimmini and Mupily watersheds, parts of Western Ghats, Thrissur District, Kerala, India. Earth Science Inform, 5, 111-121. http://dx.doi.org/10.1007/s12145-012-0101-3

Miller, V. C. (1953). A quantitative geomorphologic study of drainage basin characteristic in the Clinch Mountain area, Virginia and Tennessee. Project NR 389042, Tech Rep3, Columbia University, Department of Geology, ONR Geography Branch New York.

Narendra, K., \& Nageswararao, K. (2006). Morphometry of the meghadrigedda watershed, Visakhapatnam district, Andhra Pradesh using GIS and resourcesat data. Journal of the Indian Society of Remote Sensing, 34(2), 101-110. http://dx.doi.org/10.1007/BF02991815

Office of Natural Resources and Environmental Policy and Planning. (1999). The Registration of important international and national wetlands in Thailand. Ministry of Science, Technology and Environment, Bangkok.

Ozdemir, H., \& Bird, D. (2009). Evaluation of morphometric parameters of drainage networks derived from topographic maps and DEM in point of floods. Journal of the Indian Society of Remote Sensing, 56, 1405-1415. http://dx.doi.org/10.1007/s00254-008-1235-y

Ritter, M. E. (2006). The Physical Environment: an Introduction to Physical Geography. Retrieved from http://www.uwsp.edu/geo/faculty/ritter/geog101/textbook/title_page.html

Schumm, S. A. (1956). Evaluation of drainage systems and slopes in badlands at Perth Amboy, New Jersey. Bulletin of Geological Society of America, 67, 597-646.

Selby, M. J. (1985). Earth's changing surface. Clarendon Press, Oxford, p. 607.

Smith, K. G. (1950). Standards for grading textures of erosional topography. American Journal of Science, 248, 655-668.

Strahler, A. N. (1957). Quantitative analysis of watershed geomorphology. Transactions of American Geophysics Union, 38, 913-920. 
Strahler, A. N. (1964). Quantitative geomorphology of drainage basins and channel networks. In: Chow V.T. (ed.), Handbook of Applied Hydrology. McGraw Hill Book Company, New York.

Thomas, J., Joseph, S., Thrivikramji, K. P., \& Abe, G. (2011). Morphometric analysis of the drainage system and its hydrological implications in the rain shadow regions, Kerala, India. Journal of Geographical Sciences, 21(6), 1077-1088. http://dx.doi.org/10.1007/s11442-011-0901-2

Tiyapairat, S., \& Mahabhum, T. (1990). Report of Geological Survey and Quaternary Geological Survey in Phayao Province and Mae Chai District. Geology Division, Department of Mineral Resources, Bangkok.

Vittala, S. S., Govindaiah, S., \& Gowda, H. H. (2004). Morphometric analysis of sub-watersheds in the pavagada area of Tumkur district, South India using remote sensing and gis techniques. Journal of the Indian Society of Remote Sensing, 32(4), 101-110. http://dx.doi.org/10.1007/BF03030860

Zende, A. M., \& Nagrajan, R. (2011). Drainage morphology approach for water resources development of sub watershed in Krishna basin. International Journal of Computer and Communication Technology, 2(8), 13-21. 